\title{
Complement C3 Measurement
}

National Cancer Institute

\section{Source}

National Cancer Institute. Complement C3 Measurement. NCI Thesaurus. Code C80174.

The determination of the amount of complement C3 present in a sample. 